\title{
PELAKSANAAN PEMBINAAN NARAPIDANA \\ DALAM PERSPEKTIF UNDANG-UNDANG \\ NO. 12 TAHUN 1995
}

\author{
Nur Bagus Wahyudi, \\ Pejabat Fungsional Umum Lembaga Pemasyarakatan Kelas IIB Jombang, Indonesia \\ E-mail: bagoestwahyudi@gmail.com
}

\begin{abstract}
ABSTRAKSI
Perubahan Sistem Kepenjaraan menjadi Sistem Pembinaan di Lembaga Permasyarakatan, menimbulkan permasalahan yang bersifat umum, setelah narapidana selesai menjalani pembinaan, apakah mereka akan dapat berubah menjadi lebih baik ataukah akan mengulang tindak kejahatannya kembali. Penelitian yuridis empiris di Lembaga Pemasyarakatan Kelas IIIB Jombang menunjukkan bahwa pembinaan yang diberikan kepada narapidana yang dilakukan melalui pembinaan kepribadian dan pembinaan kemandirian sesuai dengan Peraturan Pemerintah No. 31 Tahun 1999. Pembinaan kepribadian, meliputi pembinaan kesadaran beragama, pembinaan kesadaran berbangsa dan bernegara, pembinaan kemampuan intelektual, dan pembinaan kesadaran hukum. Guna mengatasi hambatan pembinaan dari segi kualitas program pembinaan dan sumber daya manusia, dana, warga binaan, dan sarana dan fasilitasnya, maka dilakukan upaya dengan mengoptimalkan kualitas petugas lembaga pemasyarakatan, meningkatkan kesejahteraan ekonomi warga binaan dengan mengadakan pelatihan kerja, dan memelihara serta merawat sarana atau fasilitas yang ada dan mendayagunakannya secara optimal.
\end{abstract}

Kata Kunci: Pembinaan Narapidana, Undang-Undang No. 12 Tahun 1995.

\section{PENDAHULUAN}

Pada masa penjajahan Belanda tujuan hukuman di Indonesia menggunakan sistem kepenjaraan bertolak pada pemikiran bahwa manusia yang melanggar hukum adalah manusia yang jahat. Hal ini tercermin pada pelaksanaannya yang bersifat menindas. Pandangan tersebut memang mempunyai tujuan untuk memperbaiki perilaku terpidana, akan tetapi fokus perlakuannya ditujukan pada individu yang terpidana dengan menigkatkan penjagaan dalam penjara secara maksimal disertai dengan peraturanperaturan yang keras. Hal ini bukan saja menimbulkan penderitaan fisik tapi juga psikis. ${ }^{1}$

Adanya pelaksanaan pembinaan bagi narapidana di dalam Lembaga Pemasyarakatan tidak terlepas dari sebuah dinamika, yang bertujuan untuk lebih banyak memberikan bekal bagi narapidana dalam menyongsong kehidupan setelah selesai menjalani masa hukuman (bebas). ${ }^{2}$ Seperti halnya yang terjadi jauh sebelumnya, peristilahan penjara pun telah mengalami perubahan menjadi pemasyarakatan.

Lembaga pemasyarakatan berdasar Pasal 1 angka 3 Undang-undang No. 12 Tahun 1995 tentang Pemasyarakatan adalah tempat untuk melaksanakan pembinaan narapidana dan anak didik permasyarakatan. Selain itu dijelaskan bahwa Lapas sebagai ujung tombak

\footnotetext{
1 Petrus Panjaitan, 2011, Lembaga Pemasyarakatan dalam Perspektif Sistem Peradilan Pidana, Pustaka Sinar Harapan, Jakarta, h. 4.

2 Dwidja Priyatno, 2012, Menunggu Perubahan dari Balik Jeruji (Studi Awal Penerapan Konsep Pemasyarakatan). Rineka Cipta, Jakarta, h. 84.
} 
pelaksanaan asas pengayoman merupakan tempat mencapai tujuan pemasyarakatan melalui pendidikan, rehabilitasi dan integrasi. ${ }^{3}$

Lembaga Pemasyarakatan Kelas IIB Jombang sebagai salah. satu unit pelaksanaan teknis pemasyarakatan, merupakan lembaga yang secara langsung terlibat dalam pelaksanaan pembinaan narapidana. Penelitian ini bertujuan untuk mengetahui secara langsung pelaksanaan pembinaan narapidana di Lembaga Pemasyarakat Kelas IIB Jombang, serta efektivitas pelaksanaan pembinaan narapidana yang diterapkan di Lembaga Pemasyarakatan Kelas IIB Jombang sesuai Peraturan Pemerintah No. 31 Tahun 1999 tentang Pembinaan dan Pembimbingan Warga Binaan Pemasyarakatan.

Masalah pembinaan warga binaan masih memerlukan perhatian yang serius baik fisik maupun non fisik. Setelah keluar dari lembaga pemasyarakatan mereka diharapkan dapat menunaikan tugas dan kewajibannya seperti sediakala. Karena dalam lembaga pemasyarakatan itu mereka telah mendapatkan pembinaan, keterampilan, hal ini sesuai dengan salah satu tujuan lembaga pemasyarakatan yaitu memulihkan kembali kesatuan hubungan antara warga binaan dengan masyarakat. Warga binaan dalam menjalani pemidanaan berhak mendapat perlakuan secara manusiawi. Di lembaga pemasyarakatan, warga binaan memperoleh bimbingan dan pembinaan. Menumbuhkan motivasi dan kesadaran pada diri narapidana terhadap program pembinaan dan bimbingan.

\section{METODE PENELITIAN}

\section{a. Waktu dan Lokasi Penelitian}

Lokasi penelitian adalah tempat yang digunakan dalam melaksanakan penelitian untuk memperoleh data yang diinginkan. Penelitian dilaksanakan pada Januari - Februari 2017 di Lembaga Pemasyarakatan Kelas IIB Jombang karena Lembaga pemasyarakatan Kelas IIB Jombang penghuninya terpadat nomor 3 untuk Lembaga Pemasyarakatan Kelas IIB di Jawa Timur

\section{b. Desain dan Variabel Penelitian}

Penelitian ini menggunakan jenis penelitian Yuridis Empiris serta menggunakan pendekatan sosiologis empiris, yaitu pemecahan masalah yang diselidiki dengan menggambarkan atau melukiskan keadaan objek penelitian sekarang, berdasarkan faktafakta yang tampak atau sebagaimana adanya. Kemudian dari faktor-faktor yang ada akan dianalisis berdasar peraturan-peraturan yang berlaku. Jadi penelitian tentang pembinaan narapidana, dilakukan dengan menggambarkan peraturan-peraturan yang berkaitan lembaga pemasyarakatan. Kemudian dianalisis berdasar kenyataan-kenyataan yang ada dalam prakteknya.

\section{c. Populasi dan Sampel}

Metode pengambilan sampel yang digunakan dalam penelitian ini adalah dengan menggunakan purposive sampling, yaitu salah satu pengambilan sampel secara representatif berdasarkan ciri atau sifat yang memiliki keterkaitan dengan populasi sebelumnya dan mewakili populasi tersebut. Purposive sampling diterapkan apabila peneliti benar-benar ingin menjamin bahwa unsur-unsur yang hendak ditelitinya masuk ke dalam sampel yang ditariknya. Sesuai dengan metode penentuan sampel dari populasi yang akan diteliti

\footnotetext{
${ }^{3}$ Undang-undang Republik Indonesia No.12 Tahun 1995 tentang Pemasyarakatan.
} 
sebagaimana tersebut di atas maka sampel tersebut adalah pegawai Lembaga Pemasyarakatan Kelas IIB Jombang.

\section{d. Pengumpulan Data}

Dalam penelitian ini menggunakan teknik wawancara, observasi, dan dokumentasi.

1) Wawancara

Peneliti menggunakan jenis wawancara terstruktur yaitu wawancara yang pewawancaranya menetapkan sendiri pertanyaan-pertanyaan yang akan diajukan dengan disusun secara rapi. Hal ini dimaksudkan agar memperoleh informasi guna mengevaluasi pembinaan narapidana di Lembaga Pemasyarakatan Kelas IIB Jombang.

2) Observasi

Di sini peneliti melakukan observasi dengan mengamati pelaksanaan pembinaan dan hambatan yang dialami dalam memberikan pembinaan kepada narapidana. Data yang ingin peneliti dapat yaitu cara pelaksanaan pembinaan narapidana dan hambatan yang terjadi dalam pelaksanaan pembinaan kepada narapidana.

3) Dokumentasi

Data yang diperoleh yaitu dari arsip-arsip Lembaga Pemasyarakatan Kelas IIB Jombang seperti jadwal kegiatan pembinaan, surat edaran Menteri Kemenkumham tentang kewajiban bagi Lapas, surat edaran Menteri Kemenkumham tentang pelaksanaan PNBP dan program kemitraan, contoh blangko kerjasama Lapas dengan pihak luar, dan beberapa foto kegiatan pembinaan.

\section{e. Analisis Data}

Analisis data kualitatif adalah analisis yang dilakukan pada data yang berwujud kata-kata dan bukan rangkaian angka, serta dalam analisisnya tetap menggunakan kata-kata, yang biasanya disusun ke dalam teks yang diperluas. ${ }^{4}$

1) Reduksi data

Reduksi data yaitu memilih hal-hal pokok yang sesuai dengan fokus penelitian kemudian dicari temanya. Data yang telah direduksi memberikan gambaran yang lebih tajam tentang hasil pengamatan dan mempermudah peneliti untuk mencarinya sewaktu-waktu diperlukan.

2) Penyajian data

Data yang diperoleh dari observasi, wawancara dan foto mengenai bagaimana pelaksanaan pembinaan narapidana, kendala-kendala pelaksanaan pembinaan, bagaimana upaya-upaya untuk menatasi kendala-kendala tersebut dimasa mendatang yang disajikan dalam bentuk deskriptif yang melalui proses analisis, berisi mengenai uraian seluruh masalah yang dikaji.

3) Pengambilan kesimpulan (verifikasi)

Verifikasi adalah suatu kegiatan konfigurasi yang utuh di mana kesimpulan-kesimpulan diverifikasi selama penelitian berlangsung. Verifikasi itu mungkin sesingkat pemikiran kembali yang melintas dalam pikiran. Penganalisisan selama menulis, suatu tinjauan ulang pada catatan lapangan atau peninjauan kembali (Milles. 1992:18-19). Singkatnya makna-

\footnotetext{
${ }^{4}$ Burhan Bungin, 2014, Metodologi Penelitian Kualitatif, Aktualisasi Metodologi ke Arah Ragam Varian Kontemporer, Raja Grafindo Persada, Jakarta, h. 52.
} 
makna yang muncul dari data harus diuji kebenarannya, kecocokannya yang merupakan validitasnya.

\section{PELAKSANAAN PEMBINAAN NARAPIDANA DI LEMBAGA PEMASYARAKATAN KELAS IIB JOMBANG}

Lembaga Pemasyarakatan Kelas IIB Jombang sebagai salah satu unit pelaksana sistem hukuman penjara mempunyai peran yang cukup strategis dalam mengimplementasikan usaha pemerintah dalam memberikan pembinaan yang efektif kepada narapidana. Lembaga Pemasyarakatan Kelas IIB Jombang merupakan Lapas khusus karena hanya membina para narapidana. Secara garis besar model pembinaan yang dilakukan adalah menggunakan dua pendekatan yakni pendekatan dari atas (top down approach) dan pendekatan dari bawah (bottom up approach). Dalam pendekatan yang pertama, materi pembinaan berasal dari pembina atau paket pembinaan bagi narapidana telah disediakan dari atas. Narapidana tidak ikut menentukan jenis pembinaan yang akan dijalaninya, tetapi langsung saja menerima pembinaan dari para pembina. Seorang narapidana harus menjalani paket pembinaan tertentu yang telah disediakan dari atas.

Khusus bagi para tahanan, kegiatan yang diberikan kepada mereka bukan hanya semata-mata dimaksudkan sebagai kegiatan pengisi waktu agar terhindar dari pemikiranpemikiran yang negative seperti berusaha melarikan diri, tetapi harus lebih dititikberatkan pada penciptaan kondisi yang dapat melancarkan jalannya proses perkaranya di Pengadilan. Bagi bekas narapidana, pembinaan yang diberikan lebih didasarkan pada tanggung jawab moral dari pihak masyarakat karena sebenarnya mereka telah bebas.

Fungsi dan tugas pembinaan pemasyarakatan terhadap warga binaan pemasyarakatan dilaksanakan secara terpadu dengan tujuan agar mereka setelah selesai menjalani pidananya, pembinaannya dan bimbingannya dapat menjadi warga masyarakat yang baik. Sebagai abdi negara dan abdi masyarakat wajib menghayati serta mengamalkan tugas-tugas pembinaan pemasyarakatan yang berdaya guna, tepat guna dan berhasil guna, petugas harus memiliki kemampuan profesional dan integritas moral, pada dasamya arahan pelayanan, pembinaan dan bimbingan yang perlu dilakukan oleh petugas ialah memperbaiki tingkah laku warga binaan pemasyarakatan agar tujuan pembinaan dapat dicapai.

Agar pembinaan dapat berlangsung secara dua arah, maka digunakan pendekatan yang kedua yaitu pendekatan dari bawah (bottom up approach). Wujud pendekatan dari bawah (bottom up approach) ini adalah dengan diberikannya pembinaan keterampilan sesuai dengan kebutuhan belajarnya, bakat dan minat yang mereka miliki. Dengan demikian diharapkan proses pembinaan akan berjalan lancar dan dapat memenuhi sasaran yang diinginkan. Pembinaan ini memerlukan kerja keras dari pembina narapidana untuk bisa mengetahui minat dan kebutuhan belajar mereka, paling tidak mereka harus mengenal dirinya sendiri. Dan merupakan tugas dari pembina narapidana.

Ada tim khusus yang bertugas mengamati kebutuhan belajar, minat dan bakat yang dimilki oleh seorang narapidana, Tim ini dikenal dengan nama TPP (Tim Pengamat Pemasyarakatan). Selama kurang lebih satu bulan, seorang narapidana yang baru masuk akan diawasi oleh TPP untuk diketahui bakat dan minat yang dimiliki. Setelah itu barulah seorang narapidana diarahkan ke bentuk pembinaan yang sesuai dengan dirinya. Dengan 
demikian diharapkan proses pembinaan akan berjalan lancar dan dapat memenuhi sasaran yang diinginkan. mengantarkan mereka agar bisa mengenal diri sendiri.

Berdasarkan jadwal kegiatan tersebut dapat diketahui bahwa Lembaga Pemasyarakatan Kelas IIB Jombang memberikan pembinaan narapidana dengan berbagi bentuk macam kegiatan. Narapidana diberi bekal kesadaran akan pentingnya kebersihan lingkungan. Selain itu narapidana juga diberikan latihan kepramukaan untuk menambah pengetahuan dan wawasan tentang budi pekerti yang baik. Bidang keagamaan, bagi narapidana pemeluk agama Islam dilatih untuk membaca Al Quran, pelajaran agama Islam, dan pengajian. Sedangkan bagi pemeluk agama Kristen diberi pelajaran agama Kristen dan kebaktian. Bentuk lain dari kegiatan pembinaan yaitu berupa kegiatan olah raga Bola Voley.

Begitu pula dengan Lembaga Pemasyarakatan Kelas IIB Jombang, yang dalam hal ini merupakan Lembaga Pemasyarakatan khusus karena hanya membina para narapidana, harus mempunyai metode maupun bentuk pembinaan yang tepat bagi narapidana yang menghuninya. Adapun metode pembinaan yang dimaksud adalah:

1) Pembinaan berupa interaksi langsung yang sifatnya kekeluargaan antara pembina dengan yang dibina (warga binaan pemasyarakatan).

2) Pembinaan bersifat persuasi edukatif yaitu berusaha merubah tingkah laku melalui keteladanan dan memperlakukan adil di antara sesama mereka sehingga menggugah hatinya untuk melakukan hal-hal terpuji, menempatkan warga binaan pemasyarakatan sebagai manusia yang memiliki potensi dan memiliki harga diri dengan hak-hak dan kewajibannya yang sama dengan manusia lain.

3) Pembinaan berencana, terus-menerus dan sistematik.

4) Pemeliharaan dan peningkatan langkah-langkah keamanan yang disesuaikan dengan tingkat keadaan yang dihadapi.

5) Pendekatan individual dan kelompok.

\section{HAMBATAN YANG DIHADAPI DALAM PELAKSANAAN PEMBINAAN TERHADAP NARAPIDANA DI LEMBAGA PEMASYARAKATAN KELAS IIB JOMBANG}

Dari berbagai hambatan yang ada hal itu jelas menjadikan hal yang menghambat dalam proses pembinaan itu sendiri karena hambatan yang ada itu sangat berpengaruh dalam proses pembinaan itu sendiri namun petugas Lapas tetap mengupayakan langkah atau upaya yang terbaik untuk mengatasi hambatan itu ke depannya. Adapun hambatan yang dihadapi dalam pelaksanaan pembinaan terhadap narapidana di Lembaga Pemasyarakatan Kelas IIB Jombang adalah:

1) Kualitas Program Pembinaan Dan Sumber Daya Manusia

Program pembinaan sesuai dengan prosedur proses pembinaan berdasarkan Undang-Undang No.12 tahun 1995 tentang Pemasyarakatan dan didukung dengan Peraturan Pemerintah No. 31 Tahun 1999 tentang Pembinaan dan Pembimbingan Warga Binaan Pemasyarakatan, namun kurangnya sarana dan prasana, sumber daya manusia dan jumlah pegawai personil lembaga pemasyarakatan terbatas, maka pembinaan yang maksimal dan kualitas yang diharapkan agak berkurang.

2) Dana 
Dana bersumber dari pemerintah pusat sangat terbatas, sehingga anggaran tersebut hanya digunakan mencukupi operasional Lembaga Pemasyarakatan Kelas IIB Jombang, bahwa meningkatkan kesejahteraan secara ekonomi sebagai awal permodalan mandiri guna berwirausaha bagi warga binaan dilaksanakan dengan mengadakan pelatihan kerja untuk bekal hidup mandiri setelah selesai menjalani masa pidananya di lembaga pemasyarakatan.

3) Warga Binaan

Secara umum warga binaan dari segi kualitas sumber daya manusia, ketrampilan dan pendidikan wajib ditingkatkan. Namun ketika mereka diberi pembinaan masih ada warga binaan yang kurang berminat atau kurang mendalami, menghayati pembinaan yang diberikan, mereka sukanya bersantai, bergurau. Terlihat pada saat kegiatan agama Islam (pembacaan doa untuk almarhum), masih ada warga binaan atau narapidana yang mengobrol, bergurau.

4) Sarana dan Fasilitas

Sarana dan fasilitas yang dimiliki Lembaga Pemasyarakatan Kelas IIB Jombang masih ada alat-alat ketrampilan yang rusak, atau tidak bisa dipergunakan, sehingga kurang menunjang program pembinaan.

\section{UPAYA MENGATASI HAMBATAN PELAKSANAAN PEMBINAAN TERHADAP NARAPIDANA DI LEMBAGA PEMASYARAKATAN KELAS IIB JOMBANG}

1) Kualitas Program Pembinaan dan Sumber Daya Manusia

Jumlah petugas pemasyarakatan lebih sedikit dibanding jumlah warga binaan, khususnya petugas bidang pembinaan narapidana dan bidang bimbingan kerja, berdasarkan Peraturan Pemerintah No. 31 Tahun 1999 tentang Pembinaan dan Pembimbingan Warga Binaan Pemasyarakatan, salah satu upaya dalam pelaksanaan pembinaan yaitu dengan mengoptimalkan jam kerja serta program kreatif tepat guna bagi warga binaan. Bahwa pemasyarakatan mengenai kualitas dan program pembinaan serta sumber daya manusia tidak semata-mata ditentukan oleh anggaran ataupun sarana dan fasilitas yang tersedia, maka diperlukan program-program kreatif tetapi murah, mudah serta memiliki dampak eduktif yang optimal bagi warga binaan, terutama untuk program kemandirian. Masih dibutuhkan kerjasama dengan berbagai pihak dalam tugas pembinaan, kerjasama dalam instansi, yayasan sosial, LSM dalam tugas pelaksanaan pembinaan guna upaya meningkatkan kualitas warga binaan.

2) Dana

Selama ini Lapas memiliki dana bersumber dari instansi pemerintah pusat melalui Kementrian Hukum dan Hak Asasi Manusia, dengan mengoptimalkan kualitas petugas lembaga pemasyarakatan tepat, tegas dengan program pembinaan. Lembaga Pemasyarakatan telah bertransformasi dari Lembaga Konsumtif menjadi lembaga produktif, Lembaga Pemasyarakatan tidak hanya sebagai tempat membina narapidana secara konvensional, tetapi juga dapat menjadi salah satu sarana untuk mendorong dihasilkannya produk - produk berkualitas. Sesuai Peraturan Pemerintah Republik Indonesia No. 22 Tahun 1997 tentang jenis dan penyetoran penerimaan bukan pajak yang salah satunya bersumber pada penerimaan dari penggunaan jasa tenaga narapidana dan hasil penjualan barang ketrampilannya. Upaya meningkatkan 
kesejahteraan secara ekonomi warga binaan atau narapidana dilaksanakan dengan mengadakan pelatihan kerja, melalui program kerja kemandirian guna menghasilkan PNBP (Penerimaan Negara Bukan Pajak), bahwa rincian perhitungan bagi hasil kerja $80 \%$ untuk warga binaan yang mengikuti program ketrampilan bimbingan kerja, 20\% masuk Kas Negara.

3) Warga Binaan

Kualitas sumber daya manusia warga binaan perlu wajib ditingkatkan, upaya pelaksanaan yang dilakukan adalah meningkatkan minat warga binaan, mereka perlu mendapat arahan, bimbingan, dan motivasi. Pada dasarnya bakat perlu dikembangkan dalam pelaksanaan pembinaan, mereka dibekali ketrampilan guna meningkatkan kualitas sumber daya manusia, baik upaya peningkatan kesejahteraan secara ekonomis guna awal permodalan secara mandiri. Upaya kegiatan dilaksanakan melalui pembinaan kemandirian karena watak dan kepribadian perlu mendapat bimbingan siraman rohani.

4) Sarana dan Fasilitas

Menjadi tugas dan kewajiban bagi Pegawai Lembaga Pemasyarakatan Kelas IIB Jombang dan warga binaan untuk memelihara serta merawat semua sarana dan fasilitas yang ada dan mendayagunakannya secara optimal.

\section{PENUTUP}

Pembinaan yang diberikan kepada narapidana yang dilakukan melalui pembinaan kepribadian dan pembinaan kemandirian sesuai dengan Peraturan Pemerintah No. 31 Tahun 1999 tentang Pembinaan dan Pembimbingan Warga Binaan Pemasyarakatan.

a) Pembinaan kepribadian, meliputi: pembinaan kesadaran beragama, pembinaan kesadaran berbangsa dan bernegara, pembinaan kemampuan intelektual, dan pembinaan kesadaran hukum.

b) Pembinaan kemandirian, dilakukan setiap hari dimulai pada pukul $09.00 \mathrm{~s} / \mathrm{d} 13.30$ pada kegiatan keterampilan, narapidana melakukan kegiatan keterampilan seperti menyulam, menjahit, mote, renda, membuat sangkar burung, meja, kursi.

Hambatan yang dihadapi yaitu dari berbagai segi mulai dari segi kualitas program pembinaan dan sumber daya manusia, dari segi dana, dari segi warga binaan, dan dari segi sarana dan fasilitasnya. Dari berbagai hambatan yang ada hal itu jelas menjadikan hal yang menghambat dalam proses pembinaan itu sendiri karena hambatan yang ada itu sangat berpengaruh dalam proses pembinaan namun petugas Lapas tetap mengupayakan langkah atau upaya yang terbaik untuk mengatasi hambatan itu kedepannya.

Lembaga Pemasyarakatan Kelas IIB Jombang melakukan upaya mengatasi hambatan dalam memberikan pembinaan yaitu mengoptimalkan kualitas petugas lembaga pemasyarakatan tepat, tegas dengan program pembinaan. Upaya meningkatkan kesejahteraan secara ekonomi warga binaan atau narapidana dilaksanakan dengan mengadakan pelatihan kerja, melalui program kerja kemandirian guna menghasilkan PNBP (Penerimaan Negara Bukan Pajak), bahwa rincian perhitungan bagi hasil kerja 80\% untuk warga binaan yang mengikuti program ketrampilan bimbingan kerja, 20\% masuk Kas Negara. Upaya memelihara dan merawat semua sarana atau fasilitas yang ada dan mendayagunakannya secara optimal. 
Narapidana yang merupakan obyek sekaligus subyek pembinaan diharapkan berusaha sekuat tenaga untuk mengubah perilaku mereka atas dasar kemauan sendiri dan berusaha mengikuti pembinaan yang diberikan dengan sebaik-baiknya. Bagaimanapun juga pribadi mereka sendirilah yang dapat merubah perilaku negatif yang telah dilakukannya, Lapas hanya berfungsi sebagai sarana dalam proses perubahan pribadi narapidana menuju kearah yang lebih baik.

Pihak Lembaga Pemasyarakatan Kelas IIB Jombang sebagai tempat untuk membina para narapidana juga harus mampu meningkatkan mutu pembinaan terhadap para narapidana agar bisa dijadikan bekal bagi para narapidana untuk menyongsong kehidupan yang baru setelah keluar dari Lapas. Dengan bekal pembinaan yang berkualitas, para narapidana diharapkan akan dapat diterima kembali di masyarakat serta mampu bersaing di dalam kehidupan bermasyarakat.

Program dan ragam pembinaan terhadap warga binaan atau narapidana hendaknya dilaksanakan secra efektif dan kreatif serta berdaya guna untuk mengembangkan kepribadian serta peningkatan keterampilan bagi warga binaan. Diupayakan kedepan akan ada kerja sama dengan pabrik - pabrik yang ada kabupaten jombang dimana pihak pabrik yang menyediakan bahan baku dan pihak lapas yang mengerjakan dengan memanfaatkan Warga Binaan pemasyarakatan. 


\section{DAFTAR PUSTAKA}

Bungin, Burhan, 2014, Metodologi Penelitian Kualitatif, Aktualisasi Metodologi ke Arah Ragam Varian Kontemporer, Raja Grafindo Persada, Jakarta.

Departemen Hukum dan HAM, 2013, Cetak Biru Pembaharuan Pelaksanaan Sistem Pemasyarakatan, Departemen Hukum dan HAM Direktorat Jenderal Pemasyarakatan, Jakarta.

Harsono, 2013, Sistem Baru Pembinaan Narapidana, Djambatan Jakarta.

Panjaitan, Petrus, 2011, Lembaga Pemasyarakatan dalam Perspektif Sistem Peradilan Pidana, Pustaka Sinar Harapan, Jakarta.

Priyatno, Dwidja, 2012, Menunggu Perubahan dari Balik Jeruji (Studi Awal Penerapan Konsep Pemasyarakatan). Rineka Cipta, Jakarta.

Poernomo, Bambang, 2014, Pelaksanaan Pidana Penjara dengan Sistem Pemasyarakatan, Liberty, Yogyakarta.

Undang-undang Republik Indonesia No.12 Tahun 1995 Tentang Pemasyarakatan. 